The Geographical Journal of Nepal

Vol. 11: 63-76, 2018

Central Department of Geography,

Tribhuvan University, Kathmandu, Nepal

\title{
An analysis of hydraulic properties of soil based on soil texture in Chiti areas of Lamjung district in Nepal
}

\author{
Jyoti Karki ${ }^{1}$; Umesh Kumar Mandal ${ }^{1,2^{*}}$; Chabi Lal Chidi ${ }^{1},{ }^{2}$; Jitan

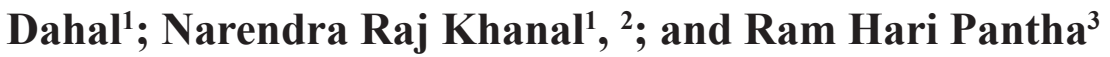 \\ ${ }^{1}$ Central Department of Geography, Tribhuvan University, Kirtipur, Kathmandu, \\ Nepal; ${ }^{2}$ Sino-Nepal Joint Research Centre for Geography, Central Department of \\ Geography, Tribhuvan University, Kathmandu, Nepal; ${ }^{3}$ Ministry of Population and \\ Environment, Singha Durbar, Kathmandu, Nepal \\ (*Corresponding Author: umesh_jee@hotmail.com)
}

Soil hydraulic properties play crucial role for having sustainable growth of vegetation and also required for carrying out environmental studies especially subsurface ground water. Since, its direct measurement is time consuming and therefore costly, indirect methods such as pedotransfer functions have been used to estimate hydraulic properties. Soil hydraulic properties: bulk density, available water, permanent wilting point, field capacity and water retention capacity and saturated hydraulic conductivity are essential to be studied. These factors affect soil productivity and the environment. The knowledge of soil water properties for different land-use and land cover types based on soil textural classes are important for re-growth of plants and agriculture crops and ultimately efficient soil and water management. The aim of this paper is to measure soil hydraulic properties based on soil textural classes for different land use types. Furthermore, the use of the soil texture triangle: hydraulic properties calculator has been assessed. The comparison of the soil hydraulic properties obtained from textural triangle for different land use land and cover types has also been analyzed. Moreover, an analysis of variance (ANOVA) of soil hydraulic properties among different land use types has been performed. The soil reaction $(\mathrm{pH})$ value ranges from 4.69 to 6.69 and as a mean of 5.51 indicating slight acidic. The analysis showed barren land occupying 14.3 percent of total land use/land cover is found to be suitable for plant growth since it has loam texture having bulk density less than $1.6 \mathrm{~g} / \mathrm{cm}^{3}$. The analysis of bulk density showed that barren land is significantly different at the 0.05 level from both agriculture and forest, whereas agriculture and forests 
are not different even at 0.05 significant levels. It verifies the fact that mean bulk density at the depth of $0.15 \mathrm{~cm}$ is affected by land use land cover types.

Keywords:Land use; soil hydraulic properties; soil texture; available water; ANOVA

\section{Introduction}

Soil is one of the most important natural resources providing life to all kinds of living beings such as plants, animals and organism. Hydraulic parameters are vital soil properties for precision agriculture and essential macro nutrient to increase soil fertility required for plant growth and development that is extremely associated with soil physical, chemical, and biological processes. Soil physico-chemical and hydraulic properties are essential to be understood for soil profile development and also for sustainable vegetation growth and development along with water balance in soils (Hillel, 1998). The behavior of hydrological characterization of different land use land cover types requires knowledge of hydraulic parameters (Santra and Das, 2008). Available water capacity (AWC) is one of the fundamental soil hydraulic properties affecting sustainable land use planning particularly soil productivity and management. Available soil water content depends upon field capacity (FC), permanent wilting point (PWP), bulk density, hydraulic conductivity governing the transport characteristics of water and solutes in soils. The knowledge of these properties is fore most concern for water retention capacity on different land- use land cover types that are required for efficient soil and water management, conservation and development of agriculture farming practices. Land use land cover change such as conversion of natural lands to cultivated fields, available water capacity is strongly influenced (Schwartz et al., 2000; Bormann and Klaassen, 2008; Zhou et al., 2008). Available water at field capacity (FC) and permanent wilting point(PWP) are essential factors to estimate the irrigation water depth that varies on distribution of land use land cover types. Soil hydraulic properties constitute the basis for understanding flow and transport processes and are important input properties in any simulations of vadose zone properties. In-depth understanding of the association or correlation between available water in soil and land use land cover types was essential in determining the flow properties of water in soil. Different researchers in different corners of the world have demonstrated the variation of soilhydraulic properties according to land-use land cover types (Sonneveld et al., 2003; Bodhinayake and Cheng, 2004; Bormann and Klaassen, 2008) and mostly affected by proportion of sand, silt, clay determining textural classes, organic matter content, bulk density and porosity (Zhou et al., 2008). Proportion of particle size of soil is necessary 
input data for the estimation of available water required for sustainable ecosystem services. For different land use land cover types, pedotransfer model led soil hydraulic properties estimator was used to estimate available soil water (Horel et al., 2015).

Accurate measurement of soil hydraulic properties is essential since it is one of the key soil properties controlling water budgets in agricultural production systems and it is done through soil test laboratories. Government of Nepal has limited soil test laboratories and recently proposed fifty new soil test laboratories to be set up on Private Public Partnership (PPP) mode with a cost of NRs 2.5 million each along with strengthening of 16 existing soil test laboratories (7 under Soil Management Directorate and 9 under National Agriculture Research Center) requiring a cost of NRs 5.0 million each to cater the demand of farmers and researchers (Dawadi et al., 2015). Estimation of these properties at an acceptable level of accuracy is important; especially in the case when they exhibit strong spatial dependence and its measurement is a time, cost and laborconsuming procedure.

In pedology, pedotransfer function(PTF) is firstly coined by as a translating data from soil survey into what we need to estimate. Based on most readily available data from such as field morphology, structure and $\mathrm{pH}$ pedotransfer functions add value to this basic information by translating them into estimates of other more laborious and expensively determined soil properties filling the gap between the available soil data and the properties which are more useful or required for a particular model or quality assessment. As a tool for modeling applications, pedotransfer functions are derived from involving various soil data measured in the field and from laboratory analyses. Soil hydraulic parameters derived through PTFs can be used to express soil hydraulic properties and water retention (Brooks and Corey,1964).

Researchers were found dealing with the estimation of FC, PWP, and Available Water Capacity(AWC), notably in a series of papers by Salter and Williams (1965) exploring relationships between texture classes and available water capacity, known as class PTFs and developed functions relating the particle-size distribution to AWC, known as continuous PTFs.

In the present attempt, pedotransfer function based on soil hydraulic properties estimator has been employed to estimate field capacity, permanent wilting point, bulk density, saturation, hydraulic conductivity and available water based on soil texture. 


\section{Methods and materials}

\section{Study area}

This study was conducted on soil in Chiti, areas, middle mountain range of Nepal which was covered by forest, grassland, agriculture and other land use types. The study site was situated with geographical extension from $28^{\circ} 09^{\prime} 55.4^{\prime \prime} \mathrm{N}$ to $28^{\circ} 13^{\prime} 50.7^{\prime \prime} \mathrm{N}$ and $84^{\circ}$ 24' 21.4" E to $84^{\circ} 27^{\prime} 30.7^{\prime \prime} \mathrm{E}$ and had an elevation of $1453 \mathrm{~m}$ with varied soils (Figure 1). According to Land Reform Mapping Project (LRMP 1984) report, the dominant soil types are entisols and inceptisols and dominant soil texture is loamy skeletal and drainage condition ranged from well to moderately well. The land slope was ranged from less than $1^{\circ}$ to more than $30^{\circ}$. The minimum and maximal average yearly temperatures were approximately found of $16.39^{\circ} \mathrm{c}$ and $28.64^{\circ} \mathrm{c}$, respectively. The mean annual total rainfall from period of 1985-2013 was found as of $3374 \mathrm{~mm}$. The landscape is composed of undulating to strongly sloping terrain. The soil depth ranges from $25 \mathrm{~cm}$ to $71 \mathrm{~cm}$.

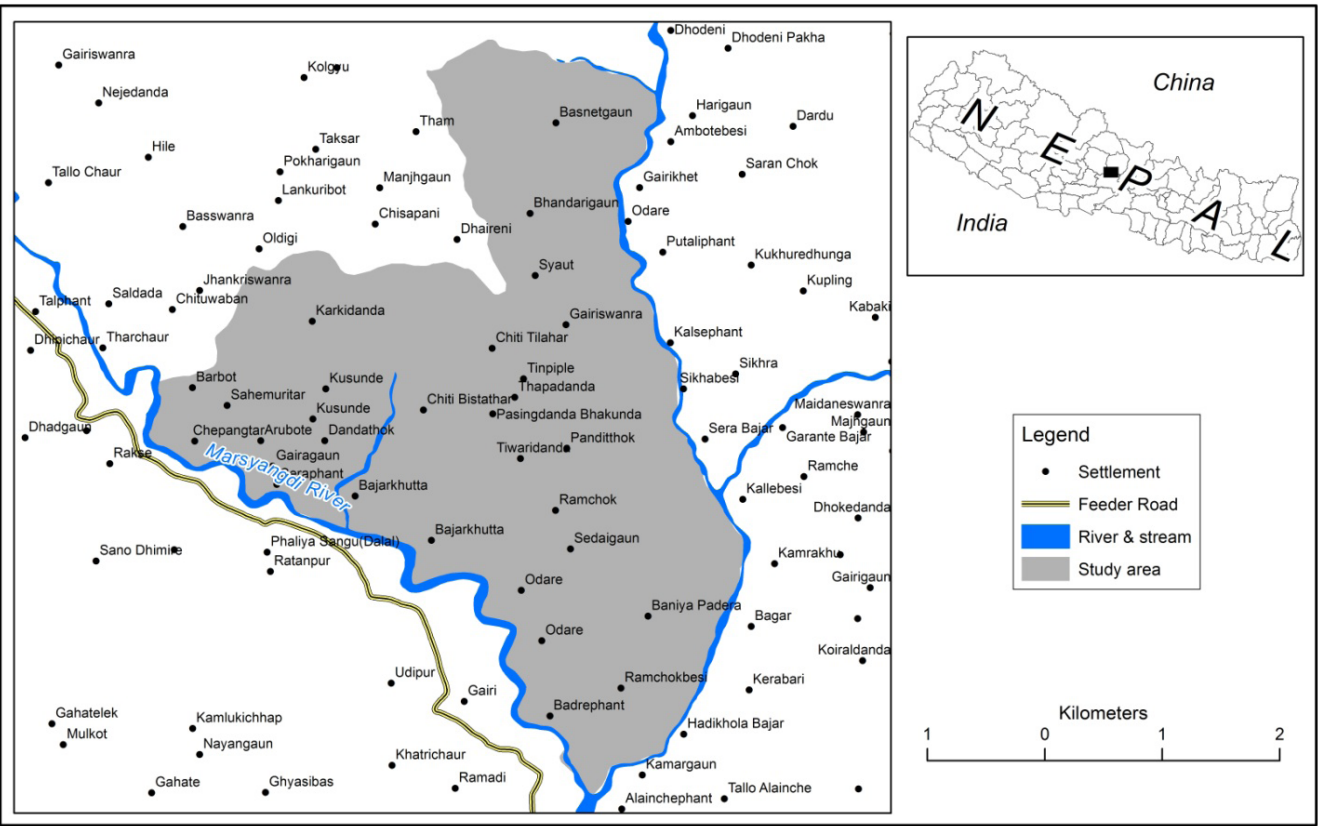

Figure1: Location map of study area 


\section{Soil sampling and data analysis}

Soil sampling units were developed based on integration of five thematic layers as landform, landscape, geology, slope and land use and land cover types.A standard soil profile description form prepared by NLUP (2017) was used in the field to capture soil profile characteristics (Karki, 2018). Representative soil samples were collected for laboratory test of primary nutrients as nitrogen, phosphorous and potassium, soil reaction and soil texture. Soil samples were collected at a depth of $0-15 \mathrm{~cm}$ at places representing each soil sampling units. Al together 35 soil samples determining by integration of five factors mentioned above were collected from five categories of land use and land cover types as cultivation, forest, grazing, bush and barren land.

The particle size distribution of soil was determined using a hydrometer method (Gee and Bouder, 1979).Soil particle sizes were separated according to the U.S. Department of Agriculture classification system: sand $(<2 \mathrm{~mm})$, silt $(0.002-<0.05 \mathrm{~mm})$ and clay $(<0.002 \mathrm{~mm})$. A wide variation of data for soil texture is observed, ranging from sandy loam to siltloam soils. The $\mathrm{pH}$ of the soil was determined with the help of a $\mathrm{pH}$ meter in 1:2.5 soil water suspension ratio.

After having homogenization, about $1 \mathrm{~kg}$ of air-dried soil was ground and sieved through a $2 \mathrm{~mm}$ mesh. Hydrometer method is most commonly used since it is less time consuming and easy to follow in a service laboratory. The soil sample is dispersed by removing the binding force in soil particles. The settling rate of dispersed particles in water is measured. Large particles are known to settle out of suspension more rapidly than do small particles. This is because larger particles have less specific area and hence have lesser buoyancy than smaller particles. Stoke's law (1851) is used to express there lationship. The law stipulates that the relabions offered by the liquid the fall of the particle varies with the radius of the sphere and not with the surface. Soil $\mathrm{pH}$ was determined by potentiometry at a soil: water ratio of 1:2.5. Figure 2 gives the distribution of samples within the soil texture triangle based on the United State's Department of Agriculture (USDA) classification.

Soil texture triangle as an estimator of soil hydraulic properties (Saxton et al., 1986) was used to estimate permanent wilting point (PWP), field capacity (FC), bulk density (BD), saturation, saturated hydraulic conductivity and available water, drainage rate. Permanent wilting point (PWP) expressed as a lower limit of available water is the water level at which water remaining in the soil is held so tightly by capillary action that it is unavailable to plants. Field Capacity (FC) also expressed as upper limit of available water, is the water content when the soil is saturated but not yet overflowing. If soils are worked with heavy machinery when they are at or above field capacity, long term damage may be done to the soil structure. 
Drainage rate is measured as the speed water travels through saturated soil. The higher this value, the more rapidly the soil will drain. Available Water (AW) is expressed as the difference between field capacity and permanent wilting point. Bulk density (BD) is expressed as 1 - saturation * 2.65 is used in determining soil porosity.

\section{Analytical tool}

Geography as a science of areal differentiation deals with the spatial variation of geographic phenomena and thus analysis of variance has been considered as the most useful technique for examining the variation of physical and chemical characteristics of soil. It has been suggested that soil science studies need to be supplemented by the analysis of variance for variation investigation with respect to soil hydraulic properties. In the present research, Analysis of Variance (ANOVA) was employed in order to examine physico-chemical and hydraulic properties of soil on each of the land use and land cover types.

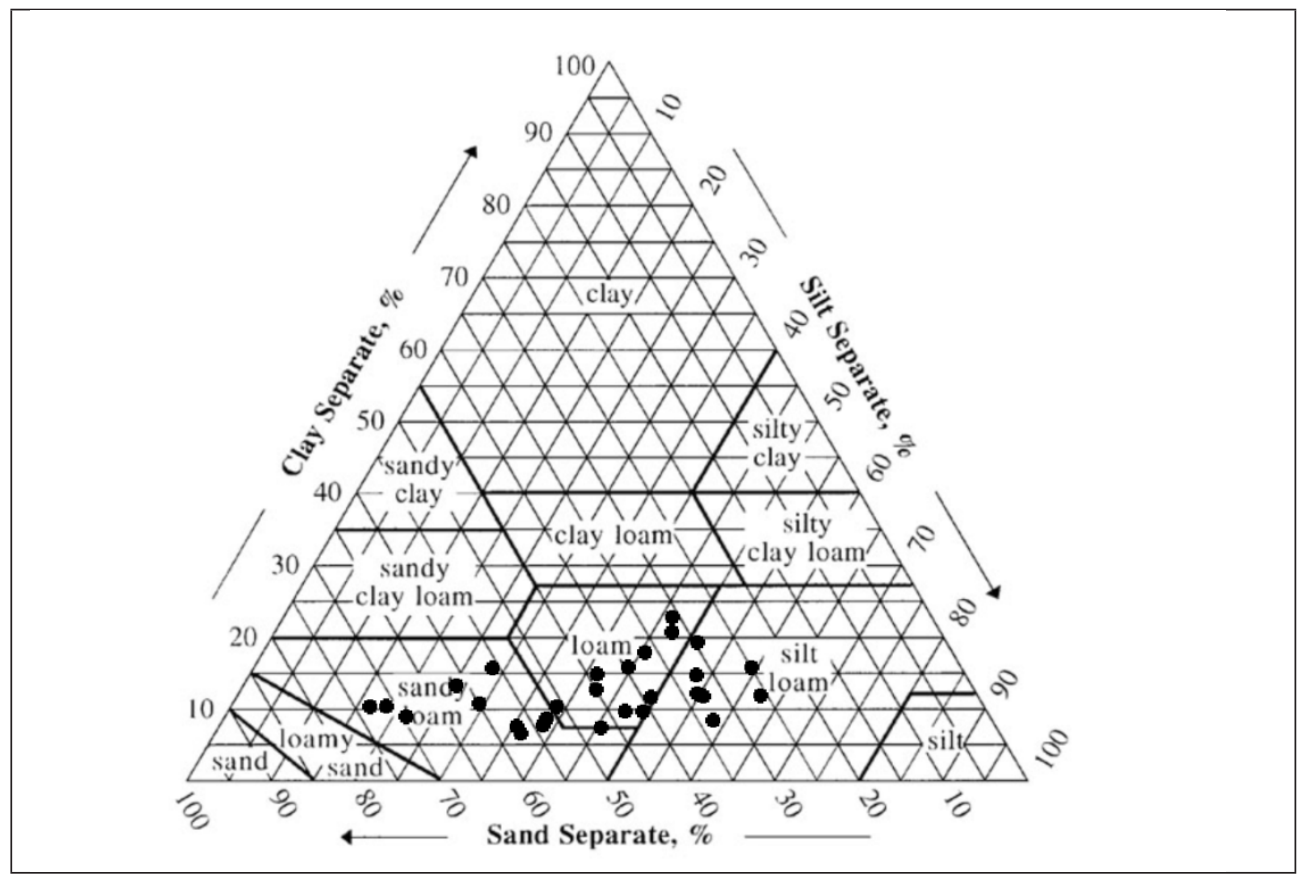

Figure 2: Distribution of samples within the soil texture triangle based on the USDA classification. 


\section{Results and discussion}

\section{Descriptive characteristics of soil}

Physico-chemical and hydraulic characteristics of soil have been analyzed using descriptive statistics. Physico-chemical properties have been included soil particle size, bulk density and $\mathrm{pH}$ and similarly hydraulic properties include permanent wilting point (PWP), field capacity (FC), saturation, drainage rate, saturated hydraulic conductivity and available water.

\section{Physical and chemical characteristics of soil}

As depicted in Table 1 which provides the descriptive statistics of soil particle size, bulk density and soil reaction $(\mathrm{pH})$ in the study area. It represents general characteristics and evidence of variations in physico-chemical parameters. The soil reaction $(\mathrm{pH})$ value ranges from 4.69 to 6.69 and as mean of 5.51 indicating slight acidic in nature. This result also verifies Nepal's major agriculture land with the dominance of acidic soil (Dawadi et al., 2015). The soil texture classes based on its proportion were ranged from sandy loam to silt loam with loam domination of 45 percent. Based on intensity of usage, and land use and land cover types, topsoil bulk density values ranged from 1.33 $\mathrm{g} / \mathrm{cm}^{3}$ to $1.62 \mathrm{~g} / \mathrm{cm}^{3}$ which was found in range of study made by Ghimire and others (Ghimire et.al., 2013).

Table 1: Physico-chemical characteristics of soil in Chiti areas $(n=35)$

\begin{tabular}{|c|l|r|r|r|r|}
\hline S.N. & Characteristics & Minimum & Maximum & Mean & Std. Deviation \\
\hline 1 & Sand $(\%)$ & 26.06 & 74.27 & 46.39 & 12.58 \\
\hline 2 & Silt $(\%)$ & 15.99 & 61.81 & 41.81 & 11.22 \\
\hline 3 & Clay $(\%)$ & 6.02 & 22.15 & 11.79 & 4.13 \\
\hline 4 & BulkDensity $\left(\mathrm{g} / \mathrm{cm}^{3}\right)$ & 1.33 & 1.62 & 1.50 & 0.07 \\
\hline 5 & $\mathrm{pH}$ & 4.69 & 6.69 & 5.51 & 0.47 \\
\hline
\end{tabular}

Source: Soil Survey 2017

\section{Hydraulic properties of soil}

Hydraulic properties of soil by representing descriptive statistics have been depicted in Table 2. It is associated with infiltration, permeability, drainage rate, erosion and ultimately available water in soil that is essential for re-growth of vegetation required for sustainable land use planning in middle hills of Nepal. Saturated hydraulic conductivity 
as one of dominant soil hydraulic properties ranged between sites from $0.77 \mathrm{~cm} / \mathrm{hr}$ to $4.37 \mathrm{~cm} / \mathrm{hr}$ as mean of $2.44 \mathrm{~cm} / \mathrm{hr}$. This range of saturated hydraulic conductivity was found to be less as compared to the study carried out by Gilmour and others (Gilmore et al., 1987) depending upon the depth of soil and method adopted. Similarly available water was found varied from $0.09 \mathrm{~cm}^{3}$ water $/ \mathrm{cm}^{3}$ soil as of minimum to $0.17 \mathrm{~cm}^{3}$ water/ $\mathrm{cm}^{3}$ soil as of maximum with the mean of $0.13 \mathrm{~cm}^{3}$ water $/ \mathrm{cm}^{3}$ soil.

Table 2: Hydraulic properties of soil in Chiti areas $(n=35)$

\begin{tabular}{|c|l|r|r|r|r|}
\hline S.N. & Characteristics & Minimum & Maximum & Mean & Std. Deviation \\
\hline 1 & $\begin{array}{l}\text { Wilting Point }\left(\mathrm{cm}^{3} \text { water/ }\right. \\
\left.\mathrm{cm}^{3} \text { soil }\right)\end{array}$ & 0.07 & 0.13 & 0.10 & 0.01 \\
\hline 2 & $\begin{array}{l}\text { FieldCapacity }\left(\mathrm{cm}^{3} \text { water/ }\right. \\
\left.\mathrm{cm}^{3} \text { soil }\right)\end{array}$ & 0.18 & 0.28 & 0.24 & 0.03 \\
\hline 3 & $\begin{array}{l}\text { Saturation }\left(\mathrm{cm}^{3} \text { water/ }\right. \\
\mathrm{cm}^{3} \text { soil) }\end{array}$ & 0.39 & 0.48 & 0.43 & 0.02 \\
\hline 4 & $\begin{array}{l}\text { Saturated hydraulic } \\
\text { conductivity (cm/hr) }\end{array}$ & 0.77 & 4.37 & 2.44 & 0.95 \\
\hline 5 & $\begin{array}{l}\text { Availablewater }\left(\mathrm{cm}^{3} \text { water/ }\right. \\
\left.\mathrm{cm}^{3} \text { soil }\right)\end{array}$ & 0.09 & 0.17 & 0.14 & 0.02 \\
\hline
\end{tabular}

Source: Soil Survey, 2017

\section{Spatial variation of physical and chemical properties of soil}

Bulk density as an indicator of soil compaction is one of the most important property among several physical properties of soil. It reflects the soil's ability to function for structural support, water and solute movement, and soil aeration. Thresholds of bulk density for different soil texture as of $<1.60 \mathrm{~g} / \mathrm{cm}^{3}$ for sandy, $<1.40 \mathrm{~g} / \mathrm{cm}^{3}$ for silty and $<1.10 \mathrm{~g} / \mathrm{cm}^{3}$ for clayey are ideal for plant growth and above these indicate impaired function restricting root growth (Arshad et al., 1996). In this connection, the study areas covered 45.7 percent, 20 percent and 34.3 percent of loam, silt loam and sandy loam as soil texture respectively and these soil textures contain bulk density of $1.45 \mathrm{~g} /$ $\mathrm{cm}^{3}, 1.46 \mathrm{~g} / \mathrm{cm}^{3}$ and $1.55 \mathrm{~g} / \mathrm{cm}^{3}$ respectively. Thus, the result shows that sandy texture as dominated in the study area are suitable for plant growth having bulk density less than $1.6 \mathrm{~g} / \mathrm{cm}^{3}$. The study reveals the fact that barren land occupying 14.3 percent of total land use/land cover was found to be suitable for plant growth since it has loam texture having bulk density less than $1.6 \mathrm{~g} / \mathrm{cm}^{3}$. 
Table 3: Analysis of variance for bulk density and soil reaction by land use /cover types

\begin{tabular}{|l|l|r|r|r|r|r|r|}
\hline \multirow{2}{*}{ Land use land cover types } & \multicolumn{3}{|c|}{ Bulk density $\left(\mathrm{g} / \mathrm{cm}^{3}\right)$} & \multicolumn{3}{c|}{$\mathrm{pH}$} \\
\cline { 3 - 9 } \multicolumn{2}{|c|}{$\begin{array}{c}\text { Mean } \\
\text { difference }\end{array}$} & $\begin{array}{c}\text { Std. } \\
\text { Error }\end{array}$ & Sig. & $\begin{array}{c}\text { Mean } \\
\text { difference }\end{array}$ & $\begin{array}{c}\text { Std. } \\
\text { Error }\end{array}$ & Sig. \\
\hline Agriculture & Forest & -0.45 & 0.34 & 0.27 & 0.12 & 0.40 & 0.25 \\
\hline Agriculture & Barren Land & $-0.99^{*}$ & 0.38 & 0.05 & $0.96^{*}$ & 0.35 & 0.02 \\
\hline Forest & Barren Land & $-0.98^{*}$ & 0.33 & 0.05 & $1.08^{*}$ & 0.35 & 0.01 \\
\hline
\end{tabular}

* The mean difference is significant at the 0.05 level.

The analysis of variance (ANOVA) for land use and land cover types on bulk density indicated that variation between land use and land cover types was significant at the 0.001 level (Table 3). Furthermore, the result of bulk density showed that barren land was significantly different at the 0.05 level from both agriculture and forest, whereas agriculture and forest land were not different even at 0.05 significant level among themselves. These conclusions suggested that bulk density of barren land could be more improved after plantation or re-forestation.

The $\mathrm{pH}$ is a master variable and its knowledge in soil is needed to understand important chemical process such as phosphate mobility, metal ion equilibria, and rate of precipitation and dissolution reactions. Moreover, soil $\mathrm{pH}$ referred to the degree of soil acidity (below 7.0) or alkalinity (above 7), is one of the essential chemical properties affecting physical, chemical, and biological properties and processes, as well as plant growth and its value of 7 is considered neutral. The nutrition, growth, and yields of most crops decrease when $\mathrm{pH}$ is low and increase as $\mathrm{pH}$ rises to an optimum level (Smith and Doran, 1996). Therefore, the lime as the quantity of limestone (CaCO3) is required to raise the $\mathrm{pH}$ of an acidic soil to a desired $\mathrm{pH}$.

The neutral of $\mathrm{pH}$ (6.0 to 7.5) is the best suitable for most of crops and macro nutrients such as calcium and magnesium, nitrate-nitrogen, phosphorus, boron, and molybdenum and they are deficient when $\mathrm{pH}$ is low, whereas aluminum and manganese are abundant, sometimes reached to toxic level for some plants. Similarly, phosphorus, iron, copper, zinc, and boron are frequently deficient in the very alkaline soils. At low level of $\mathrm{pH}$, bacterial populations and their activities are declined whereas at large range of $\mathrm{pH}$ from acidic to alkaline, fungiare adapted and most of micro-organisms need an optimum $\mathrm{pH}$ range for survival and function (Brady and Weil, 1999). 
In this connection, the study areas covered 45.7 percent, 20 percent and 34.3 percent loam, silt loam and sandy loam as soil texture respectively, and these soil textures contain bulk density of $1.45 \mathrm{~g} / \mathrm{cm}^{3}, 1.46 \mathrm{~g} / \mathrm{cm}^{3}$ and $1.55 \mathrm{~g} / \mathrm{cm}^{3}$ respectively. Thus, the result shows that sandy texture as dominated in the study area are suitable for plant growth having bulk density less than $1.6 \mathrm{~g} / \mathrm{cm}^{3}$. The study reveals the fact that barren land occupying 14.3 percent of total land use/land cover was found to be suitable for plant growth since it has loam texture having bulk density less than $1.6 \mathrm{~g} / \mathrm{cm}^{3}$.

The mean $\mathrm{pH}$ of the tested samples taken from different sites of the study area was 5.51 ranging from 4.69 as of minimum and 6.69 as of maximum. The majority (74.2\%) were ranged from strongly acidic to moderately acidic while, remainings $17.1 \%, 5.7 \%$ and $2.9 \%$ of the analyzed samples were very strongly acidic, slightly acidic and nearly neutral respectively. This result matched with the findings of Nepalese soils where $70 \%$ are acidic in nature (Dawadi et al 2015). As considering by land use land cover types, agriculture land was pre-dominated by strongly acidic soil reaction whereas forest was found equally dominated by strongly acidic and moderately acidic. In case of barren land, soil reaction was found moderately to slightly acidic in nature.

In evaluating spatial behavior of soil reaction $(\mathrm{pH})$ by the analysis of variance for all land use and land cover types, it was revealed that the land use and land cover types were significantly different at the 0.05 level (Table 3 ). Barren land was significantly different from agriculture and forest land at 0.05 level. Agriculture and forest land was not significantly different from each other at the 0.05 level. Two homogeneous subsets were clubbed or grouped on soil reaction at the 0.05 significant level. First subset included agriculture and forest significantly different from barren land. The second subset included barren land only (Table 3 ).

\section{Spatial variation of hydraulic properties of soil}

The mean saturated hydraulic conductivity and available water of the tested samples of the study sites were $2.44 \mathrm{~cm} / \mathrm{hr}$ and $0.138 \mathrm{~cm}^{3}$ water/ $\mathrm{cm}^{3}$ soil respectively. The mean saturated hydraulic conductivity for agriculture, forest and barren land were estimated to be $2.53 \mathrm{~cm} / \mathrm{hr}, 2.62 \mathrm{~cm} / \mathrm{hr}$ and $1.68 \mathrm{~cm} / \mathrm{hr}$ respectively. Similarly available water for agriculture, forest and barren land at field capacity $(\mathrm{FC})$ and permanent wilting point (PWP) were estimated as of $0.141 \mathrm{~cm}^{3}$ water/ $\mathrm{cm}^{3}$ soil, $0.133 \mathrm{~cm}^{3}$ water $/ \mathrm{cm}^{3}$ soil and $0.141 \mathrm{~cm}^{3}$ water $/ \mathrm{cm}^{3}$ soil respectively. 
Table 4: Analysis of variance

\begin{tabular}{|l|l|r|r|r|r|r|r|}
\hline \multirow{2}{*}{ Land use land cover types } & \multicolumn{3}{|c|}{$\begin{array}{c}\text { Saturated hydraulic } \\
\text { conductivity }(\mathrm{cm} / \mathrm{hr})\end{array}$} & \multicolumn{3}{|c|}{$\begin{array}{c}\text { Available water }\left(\mathrm{cm}^{3} \text { water/ }\right. \\
\mathrm{cm}^{3} \text { soil }\end{array}$} \\
\cline { 3 - 9 } \multicolumn{2}{|c|}{$\begin{array}{c}\text { Mean } \\
\text { difference }\end{array}$} & $\begin{array}{c}\text { Std. } \\
\text { Error }\end{array}$ & Sig. & $\begin{array}{c}\text { Mean } \\
\text { difference }\end{array}$ & $\begin{array}{c}\text { Std. } \\
\text { Error }\end{array}$ & Sig. \\
\hline Agriculture & Forest & -0.08 & 0.34 & 0.97 & $0.01^{*}$ & 0.01 & 0.05 \\
\hline Agriculture & Barren Land & $0.85^{*}$ & 0.47 & 0.05 & 0.01 & 0.01 & 1.00 \\
\hline Forest & Barren Land & $0.93^{*}$ & 0.49 & 0.05 & $-0.02^{*}$ & 0.01 & 0.47 \\
\hline
\end{tabular}

* The mean difference is significant at the 0.05 level.

Spatial analysis with high values of saturated hydraulic conductivity was geographically distributed in forest land. In evaluating spatial pattern of this hydraulic parameter by analysis of variance for all land use and land cover types, it was revealed that barren land was significantly different from agriculture and forest land at the level of 0.05 ( Table 4). Similarly in terms of available water, forest was significantly different from agriculture and barren land at the 0.05 level since permanent wilting point of forest was found significantly different from agriculture and barren land. Thus, two homogeneous groups were formed in terms of having same mean value of available water. They were agriculture and barren land in one group and forest in other group.

Thus the result of available water at field capacity (FC) and permanent wilting point (PWP) as an important estimator of the irrigation water depth and saturated hydraulic conductivity were affected by land-use land, cover types

\section{Conclusion}

This paper has focused on sustainable land use planning by proper management of agriculture land and re-forestation on barren land with efficient management of forest resources that leads to increase livelihood options of the rural population. For achieving this, hydraulic parameters are vital soil properties for enhancing water retention capacity required for plant growth and development which is basically associated with soil's physical, chemical, and biological processes. Hydraulic properties can be obtained from direct laboratory and field measurements. However, those techniques are limited in terms of time consumption and economy. Thus, pedo-transfer function based soil hydraulic properties estimator was employed to estimate field capacity, permanent wilting point, bulk density, saturation, hydraulic conductivity and available water based on existing soil texture.

The soil reaction $(\mathrm{pH})$ of the study area value ranges from 4.69 to 6.69 and as mean of 5.51 indicating moderately acidic soil in nature and it requires proper lime addition. 
The dominant soil texture of the study was loam occupying 45 percent of spatial extent. Similarly, topsoil bulk density values ranged from $1.33 \mathrm{~g} / \mathrm{cm}^{3}$ to $1.62 \mathrm{~g} / \mathrm{cm}^{3}$ with mean of $1.50 \mathrm{~g} / \mathrm{cm}^{3}$. Saturated hydraulic conductivity ranged between sites from $0.77 \mathrm{~cm} /$ hr to $4.37 \mathrm{~cm} / \mathrm{hr}$ as mean of $2.44 \mathrm{~cm} / \mathrm{hr}$.The study reveals the fact that barren land occupying 14.3 percent of total land use/land cover was found to be suitable for plant growth since it has loam texture having bulk density less than $1.6 \mathrm{~g} / \mathrm{cm}^{3}$. The result of bulk density showed that barren land was significantly different at the 0.05 level from both agriculture and forest land, whereas agriculture and forests land were not different even at 0.05 significant level. It verifies the fact that mean bulk density at the depth of $0-15 \mathrm{~cm}$ is affected by land use and land cover types. The mean saturated hydraulic conductivity was significantly greater in forest when compared with agriculture and barren land. It can be improved by plantation in barren land and proper management of crops in agriculture.The results of this study encourage further investigations of remaining physical, chemical and hydraulic properties of existing soil for afforestation in barren land and sustainable agriculture planning for improving livelihood condition of the rural communities in the study areas.

\section{Acknowledgements}

The present paper is based on the study supported by the project "Ecosystem-based Adaptation through South-South Cooperation (EbA South)", which is a full-sized GEF project, funded through the Special Climate Change Fund. Officially known under the title "Enhancing Capacity, Knowledge and Technology Support to Build Climate Resilience of Vulnerable Developing Countries", the project is implemented by United Nations Environment Programme and executed by the National Development and Reform Commission of China through the Institute of Geographic Sciences and Natural Resources Research, Chinese Academy of Sciences.

The test of soil samples was carried out in the soil laboratory of Sino-Nepal Joint Research Centre for Geography within the Central Department of Geography which was established with the help of Institute of Mountain Hazards and Environment (IMHE), Chinese Academy of Sciences (CAS), Chengdu and financial support from the Ministry of Science and Technology, China. The authors would like to thank the EbA South project for its support to the fieldwork and Sino-Nepal Joint Research Centre for Geography for laboratory facilities.

The authors would also like to thank Dr. Anthony Mills, Dr. Pierree Begat and Dr. Robert Raw from C4 Eco Solutions, Prof. Deng Wei and Prof. Xiong Donghong from IMHE and two unanimous reviewers for their help in improving the manuscript by providing comments and suggestions. 


\section{References}

Arshad, M.A., Lowery, B., \& Grossman, B. (1996). Physical Tests for Monitoring Soil Quality. In: Doran J.W., \& Jones A.J., editors. Methods for assessing soil quality. Madison, WI. P. 123-41.

Bormann, H., \& Klaassen, K. (2008). Seasonal and land use dependent variability of soil hydraulic and soil hydrological properties of two Northern German soils. Geoderma, 145:295-302.

Bodhinayake, W., \& Cheng, S. B. (2004). Near-saturated surface soil hydraulic properties under different land uses in the St. Denis National Wildlife Area. Hydrol Process. 18:2835-2850.

Bouma, J. (1989). Using soil survey data for quantitative land evaluation Advances Soil Science, 9: 177-213.

Brady, N. C., \& Weil, R. R. (1999). Elements of the Nature and Properties of Soils. Abrid 12 ed. Prentice-Hall. Upper Saddle River, NJ.

Brooks, R. H., Corey, A. T. (1964). Hydraulic properties of porous media. Civil Engineering Department, Colorado State University, FortCollins, CO.

Dawadi, D. P, Risal, C. P., Maskey, K. H., Rijal, B., \& Thapa, T. B., (2015). Mobile Soil Test Laboratory: Experience of Soil Management Directorate to aware Farmers about Soil Health Proceedings of the Second National Soil Fertility Research Workshop "Celebrating International Year of Soils ,2015" Healthy Soils for Healthy Life “ 24-25 March, 2015, Organized by: , CIMMYTE, IRRI, Soil Science Division Nepal Agricultural Research Council(NARC), Khumaltar Lalitpur, Nepal.

Gee, G. W., and J. W. Bauder (1979). Praticle Size by Hydrometer: A Simplified Method for Routine Textural Analysis and Sensitivity Test of Measurment Parameters. Journal of Soil Science Society of America, 43: 1004-1007.

Ghimire, C. P., Bonell, M., Bruijnzeel, L. A. \& Coles, N. A., \& Lubczynski, M. W. (2013). Reforesting severely degraded grassland in the Lesser Himalaya of Nepal: Effects on soil hydraulic conductivity and overland flow production. Journal of Geophysical Research: Earth Surface, 118: 2528-2545, doi: 10.1002/2013JF002888.

Hillel, D. (1998). Environmental soil physics. Academic Press Inc., New York

Horel, Á., Eszter, T., Györgyi ,G., Ilona, K., Zsófia, B., \& Csilla, F. (2015) .Effects of Land Use and Management on Soil Hydraulic Properties. Open Geosci, 1:742-754.

Karki, J. (2018). Characterization of soil: A case study of Chiti area of Lamjung district, Western Nepal. Master's thesis, Central Department of Geography, TU, Kathmandu, Nepal. 
LRMP (1986). Land Capability Report. Ottawa, Canada: Land Resource Mapping Project, Kenting Earth Sciences Limited.

NARC (2013), Methods of soil sample collection and analysis. Soil Science Division, Council of National Agriculture Research, National Agriculture Research Center, Khumaltar, Lalitpur, Nepal.

Tobella, A. B., Reese, H., Almaw, A., Bayala, J., Malmer, A., Laudon, H., \& Ilstedt, U. (2014). The effect of trees on preferential flow and soil infiltrability in an agroforestry parkland in semiarid Burkina Faso. Water Resources Research, 50: 3342-3354. https://doi.org/10.1002/2013wr015197.

Salter, P. J., \& Williams, J. B. (1965). The influence of texture on the moisture characteristics of soils: A critical comparison of techniques for determining the available-water capacity and moisture characteristic curve of a soil. European .Journal of Soil Science, 16(1): 1-15.

Santra, P., \& Das B. S. (2008). Pedotransfer functions for soil hydraulic properties developed from a hilly watershed of Eastern India. Geoderma, 146:439-448.

Saxton K. E., Rawls, J.W., Romberger, J. S. \& Papendick, R. I. (1986). Estimating generalized soil-water characteristics from texture. Soil Sci. Soc. Amer. J.,50(4):1031-1036.

Schwartz, R. C., Unger, P. W, \& Evett, S. R., (2000). Land use effects on soil hydraulic properties (book series 5)International Soil Tillage Research Organization, Netherland

Smith, J. L. \& Doran, J. W. (1996). Measurement and use of pH and electrical conductivity for soil quality analysis.In Doran, J. W. \& Jones, A. S. (eds) Methods for Assessing Soil Quality.Soil Science Society of America Special Publication, 49: 169-182.

Sonneveld, M. P. W., Backx, M. A. H. M., \& Bouma, J. (2003). Simulation of soil water regimes including pedotransfer functions and land use related preferential flow. Geoderma, 112:97-110.

Stokes, G. G. (1851). On the Effect of the Internal Friction of Fluids on the Motion of Pendulums. Cambridge Philos. Trans., 9: 8-106,

USDA/NRCS (2005).National Soil Survey Handbook, 430-VI. Soil Properties and Qualities (Part 618), Available Water Capacity (618.05). United States of Department of Agriculture, Natural Resources Conservation Service.

Zhou, X., Lin, H. S., \& White, E. A. (2008).Surface soil hydraulic properties in four soil series under different land uses and their temporal changes.Catena, 73:180188. 